\title{
Sources of Resistance to Bacterial Wilt Found in Vietnam Collections of Pepper (Capsicum annuum) and Their Nuclear Fertility Restorer Genotypes for Cytoplasmic Male Sterility
}

\author{
Ngoc Hung Tran ${ }^{1,2}$ and Byung-Soo Kim ${ }^{1 *}$ \\ ${ }^{1}$ Department of Horticulture, Kyungpook National University, Daegu 702-701, Korea \\ ${ }^{2}$ Fruits and Vegetables Research Institute (FAVRI), Trau Qui-Gia Lam, Hanoi, Vietnam \\ (Received on January 26, 2012; Revised on July 12, 2012; Accepted on July 17, 2012)
}

Eleven hot pepper accessions collected in Vietnam showed stable resistance to bacterial wilt as well-known resistance sources, MC4 and MC5, in repeated inoculation tests with different Ralstonia solanacearum isolates conducted from 2004 to 2010 . Seven of these accessions (specifically KC981, KC1006, KC1021, KC1027, KC1045, $\mathrm{KC1050}$, and $\mathrm{KC1055)}$ resulted in stable male sterile $F_{1}$ plants in the crosses with a cytoplasmically male sterile (CMS) Chilseong (CMS-A, Srfrf), and therefore, they were maintainers (CMS-B) with a genotype of Nrfrf. The rest (KC980, KC995, KC999, and KC1009) produced stable male fertile $F_{1}$ plants in the crosses, and therefore, were restorers (CMS-C) with a genotype of $N(S) R f R f$. Therefore, the maintainer and restorer sources of resistance may be used in preference in breeding maternal (CMS and their maintainers) and paternal parents (restorers) for resistance to bacterial wilt, respectively, in the hybrid breeding system utilizing cytoplasmic male sterility.

Keywords : breeding, Capsicum annuum, cytoplasmic male sterility (CMS), Ralstonia solanacearum, resistance

The Chili pepper (Capsicum annuum) is widely grown in Vietnam with a diversity of climatic conditions and different local consumer's preferences. Local pepper collections have been carried out in Vietnam, and maintained in the Fruit and Vegetable Research Institute (Hanoi) since 1996. However, their reactions to main diseases attacking pepper were still poorly understood. Bacterial wilt caused by Ralstonia solanacearum affects more than 200 plant species, and occurs in most tropical, subtropical and warm temperate areas (Hayward, 1994). R. solanacearum enters plant roots through wounds or natural openings. Once it gets inside the xylem, the bacterium multiplies and spreads rapidly throughout the plant's vascular system. Susceptible

\footnotetext{
*Corresponding author.

Phone)+82-53-950-5729, FAX) +82-53-950-5722

E-mail) bskim@knu.ac.kr
}

plants respond by wilting, yellowing and dying. The disease occurs mainly in Asian countries (Kennet et al., 1970). In Vietnam, the disease damages $20-40 \%$, 25-45\% and $20-30 \%$ of potato, tomato and groundnut production areas, respectively (Doan et al., 2006). Pepper cultivated in Southeast Asia is often confronted by the different biovars and strains of the bacterium, ranking this pathogen as the fourth major disease of the crop. The disease is also widely observed in Japan (Horita and Tsuchiya, 2001). The causal bacterium is soil-borne with an extremely wide host range and persistence in the environment (Hayward, 2000). Although there are several methods to control the disease such as field sanitation, crop rotation and use of bactericides, host plant resistance has been a major strategy for managing bacterial wilt in pepper. Some resistant pepper accessions have already been found such as MC5, PBC631, PI322727, PI358812, PBC066, Kerting, PI322726, PI369994, PI369998, PI377688, KC00382, PI322728 (Kim et al., 1998; Matos et al., 1990), and LS2341 (Mimura and Yoshikawa, 2009). However, $R$. solanacearum is highly heterogeneous. So, the resistance to bacterial wilt can be location-specific (Hanson et al., 1996). In fact, damage has been observed in the pepper cultivars Fushimi-amanaga and Manganji which were previously known to be resistant (Hashimoto et al., 2001). Thus, it is necessary to find more diverse resistant sources to genetically cope with the highly variable strains of the pathogen.

Cytoplasmic male sterility (CMS) resulting from interaction between the cytoplasmic and nuclear genes was found in Capsicum by Peterson in 1958 and its morphology was investigated in 1974 by Horner and Rogers. CMS is a maternally inherited character, causing plants to fail to produce functional anthers, pollen grains or male gametes. The advantage of a CMS system is that male sterile plants can generate homozygous offspring in sterility, being an economically important trait in $\mathrm{F}_{1}$ hybrid seed production by avoiding hand emasculation steps. However, unstable sterility can happen under cool conditions (Novak et al., 1971; Shifriss and Frankel, 1971; Shifriss and Guri, 1979). 
In Korea, most hybrid seeds of hot peppers are produced by means of CMS, containing 3 lines: line A (Srfrf), line B (Nrfrf) and line C $(N(S) R f R f)$ (Yu, 1990). Depending on their nuclear genotype for the CMS-restoring gene $(R f)$, pepper lines can be classed as either maintainers (Nrfrf) or restorers $(N(S) R f R f)$. With the aim of breeding $\mathrm{F}_{1}$ hybrid pepper resistant to bacterial wilt, we identified the nuclear genotype of the new sources of resistance to $R$. solanacearum with respect to the fertility-restoring gene $(R f)$ for male sterile cytoplasm.

Seeds of 116 pepper accessions from Vietnam and 29 others from Korea and Nepal were sown in September 2004 in 128-cell trays filled in with 'Wonjo Mix' medium (Nongkyung Co., Ltd., Korea). Sixteen seedlings of each accession were raised to 2-3 foliage leaf stage in 32-cell trays and inoculated artificially with $R$. solanacearum suspension at about one month after sowing. After disease evaluation, 3 healthy plants of each resistant accession were selected and grown in big pots containing $2 \mathrm{~kg}$ of 'Wonjo Mix' medium for seed production. Seeds of 41 Vietnamese accessions harvested from the first selection were sown for the confirmative evaluation in 2005 with some other known resistant and susceptible controls. Sixteen plants of each line of one-month-old seedlings were inoculated by dipping the roots in the bacterial cell suspension in 3 replications of a completely randomized design. Disease-free plants in the resistant accessions were continuously selected for further research. In 2010, the 2 different isolate inoculations were implemented with 36 materials of which 7 Vietnamese accessions were involved.

A highly virulent isolate of $R$. solanacearum from Miryang (Korea) was selected and used in the inoculations in 2004 and 2005. New fresh isolates from Miryang and Sangju, Korea were used in the 2010 evaluation. Seedlings were inoculated at around 30 days after sowing. Inoculum was prepared by harvesting the 48-hour culture of the pathogen on TTC medium (Schaad et al., 2001). Seedlings were pulled out from 128-cell trays and dipped in bacterial suspension of $10^{7} \mathrm{cfu} / \mathrm{ml}(\mathrm{OD}=0.14$ at $600 \mathrm{~nm})$, then transplanted to 32-cell trays. Inoculated seedlings were maintained in the greenhouse at around $25-35^{\circ} \mathrm{C}$, and routinely watered. Disease evaluations were done from 20 30 days after inoculation. The severity of wilting symptoms of individual inoculated plants was rated on a scale of 1 to 5 , where: $1=$ no visible symptoms; $2=$ one to less than half of the foliage wilting; 3 = about half of the foliage wilting; 4 $=$ nearly all of the foliage wilting; $5=$ the whole plant wilting and dead. Data was statistically analyzed by SAS program.

On the basis of preliminary screening in 2004, confirmative evaluation in 2005, and evaluation to two different strains in 2010, the 11 best Vietnam accessions, which are

Table 1. Reaction to Ralstonia solanacearum of selected Capsicum pepper accessions collected in Vietnam

\begin{tabular}{|c|c|c|c|c|c|c|}
\hline \multirow[b]{2}{*}{ Accession } & \multirow[b]{2}{*}{ Origin } & \multicolumn{4}{|c|}{ Disease index ${ }^{a}$ to strain of } & \multirow[b]{2}{*}{ Previous report } \\
\hline & & $\begin{array}{c}\text { Miryang } \\
(2004)\end{array}$ & $\begin{array}{c}\text { Miryang } \\
(2005)\end{array}$ & $\begin{array}{l}\text { Miryang } \\
(2010)\end{array}$ & $\begin{array}{l}\text { Sangju } \\
(2010)\end{array}$ & \\
\hline KC980 & Vietnam & 1.1 & $1.4 \mathrm{ab}^{\mathrm{b}}$ & $1.5 \mathrm{a}-\mathrm{d}$ & $1.4 \mathrm{a}-\mathrm{d}$ & \\
\hline KC981 & Vietnam & 1.0 & $1.9 \mathrm{a}-\mathrm{h}$ & $-^{\mathrm{c}}$ & - & \\
\hline KC995 & Vietnam & 1.0 & $1.6 \mathrm{a}-\mathrm{e}$ & $1.3 \mathrm{ab}$ & $1.1 \mathrm{ab}$ & \\
\hline KC999 & Vietnam & 1.1 & $1.7 \mathrm{a}-\mathrm{f}$ & $1.1 \mathrm{a}$ & $1.1 \mathrm{ab}$ & \\
\hline $\mathrm{KC} 1006$ & Vietnam & 1.0 & $1.7 \mathrm{a}-\mathrm{f}$ & $1.9 \mathrm{a}-\mathrm{e}$ & $1.0 \mathrm{a}$ & \\
\hline KC1009 & Vietnam & 1.1 & $2.2 \mathrm{a}-1$ & $1.1 \mathrm{a}$ & $1.1 \mathrm{ab}$ & \\
\hline $\mathrm{KC} 1021$ & Vietnam & 1.0 & $1.6 \mathrm{a}-\mathrm{c}$ & - & - & \\
\hline $\mathrm{KC} 1027$ & Vietnam & 1.0 & $2.0 \mathrm{a}-\mathrm{i}$ & - & - & \\
\hline $\mathrm{KC} 1045$ & Vietnam & 1.1 & $2.2 \mathrm{a}-1$ & - & - & \\
\hline $\mathrm{KC} 1050$ & Vietnam & 1.0 & $1.6 \mathrm{a}-\mathrm{d}$ & $1.9 \mathrm{a}-\mathrm{e}$ & $1.1 \mathrm{ab}$ & \\
\hline $\mathrm{KC} 1055$ & Vietnam & 1.0 & $2.1 \mathrm{a}-\mathrm{k}$ & $1.5 \mathrm{a}-\mathrm{d}$ & $1.3 \mathrm{a}-\mathrm{c}$ & \\
\hline $\mathrm{KC} 126$ & PI358812 & 1.0 & $2.1 \mathrm{a}-\mathrm{o}$ & $2.4 \mathrm{c}-\mathrm{g}$ & $1.0 \mathrm{a}$ & Kim et al., 1998 \\
\hline KC350 & $\mathrm{MC4}$ & 1.2 & $2.0 \mathrm{a}-\mathrm{j}$ & $1.0 \mathrm{a}$ & $1.0 \mathrm{a}$ & Perera et al., 1983 \\
\hline KC351 & MC5 & 1.2 & $1.3 \mathrm{a}$ & $1.2 \mathrm{a}$ & $1.1 \mathrm{ab}$ & Matos et al., 1990 \\
\hline KC1262 & ANN647 & - & $4.3 v-y$ & $4.5 \mathrm{j}$ & $3.6 \mathrm{fg}$ & \\
\hline Cheonhatongil & $\mathrm{F}_{1}$ hybrid & - & $4.8 \mathrm{y}$ & - & - & \\
\hline
\end{tabular}


comparable to the known sources of resistance to bacterial wilt such as PI358812, MC4 and MC5 (Kim et al., 1998; Matos et al., 1990), were selected and the results are given in Table 1. Because of the high temperature in the summer inoculation in 2005, many resistant accessions found in 2004 tended to susceptibility. In the 2010 test, KC1006, $\mathrm{KC1050}$, and KC126 (PI358812) showed some differential reaction to the two different strains of the bacterium, but all the others performed consistently. The Vietnamese accessions were collected throughout the country from 1996 and maintained at the Fruit and Vegetable Research Institute (Hanoi, Vietnam) by periodic increase of seed in the net house. Although pepper is predominantly self-pollinated, a degree of out-crossing may occur (Tanksley, 1984). The homozygosity level of the accessions used in this study at the beginning was not known. Therefore, the resistant plants of each accession were continuously self-pollinated and selected until 2010 to obtain homozygosity in the selections.

Inheritance of resistance to this pathogen had been studied in some of these accessions, and the results showed that resistance to $R$. solanacearum in pepper was a quantitative character, and was governed by oligogenic or polygenic inheritance. The resistance was inherited in partial dominance to recessive mode (Tran and Kim, 2010). Although a hypersensitive type of response to $R$. solanacearum has been reported in some species (Arlat et al., 1994; Carney and Denny, 1990), none of these Capsicum pepper accessions was found hypersensitive or immune. Rahman et al. (1999) found that restriction of the spread of the pathogen was associated with resistance to bacterial wilt in $C$. annuum and was mainly attributed to some induced, morphological and physical barriers. In addition, KC995, KC1006, and
$\mathrm{KC} 1027$ of them were also resistant to bacterial spot caused by Xanthomonas euvesicatoria (Tran and Kim, 2007). Thus, they may be good materials for breeding multiple resistances to bacterial wilt and bacterial spot.

The resistant accessions were crossed to a cytoplasmically male sterile Chilseong (CMS-A, Srfrf ) in 2009. Seeds of the $\mathrm{F}_{1}$ 's were sown in 128-cell trays filled with 'Wonjo Mix' medium. One month after sowing, seedlings were transplanted to 32-cell trays. Fertility of the $F_{1}$ plants was examined by visual observation of anthers for production of pollens with the aid of a magnifier as the first flowers on the plants began to bloom. Pollen parents were classified into restorer $(N(S) R f R f)$ or maintainer $(N r f r f)$ of cytoplasmic male sterility on the basis of their ability to produce male fertile $F_{1}$ plants in the crosses with a cytoplasmic male sterile Chilseong with Srfrf plasma-genotype.

The results of fertility examination of $\mathrm{F}_{1}$ 's between the CMS Chilseong (Srfrf) and bacterial wilt resistant selections showed that KC350, KC980, KC995, KC999, and $\mathrm{KC} 1009$ were producing male fertile $\mathrm{F}_{1}$ plants, and therefore, were restorers carrying the $N(S) R f R f$ genotype (Table 2). The others, KC351, KC981, KC1006, KC1021, KC1027, $\mathrm{KC} 1045$, $\mathrm{KC1050}$, and $\mathrm{KC1055}$, produced male sterile $\mathrm{F}_{1}$ plants and were identified as maintainers carrying the Nrfrf genotype (Table 2). The results agreed with the previous report of Kim et al. (2004) that KC350 and KC351 were a restorer and a maintainer, respectively. In cytoplasmic male sterility system, instability in maintenance and restoration of cytoplasmic male sterility was often observed in sweet or fresh fruit type pepper (Lee, 2001; Shifriss, 1997). The accessions used in this study were all pungent types and instability was not observed in any stage of the study.

The bacterial wilt resistant accessions of $C$. annuum from

Table 2. Male fertility of $\mathrm{F}_{1}$ 's between a cytoplasmic male sterile line, Chilseong-A (Srfrf) and sources of resistance to Ralstonia solanacearum found in Vietnam peppers, their nuclear restorer genotypes for male sterile cytoplasm, and fruit characters

\begin{tabular}{ccccccc}
\hline \hline Accession & $\begin{array}{c}\text { Male fertility } \\
\text { of } F_{1}\end{array}$ & $\begin{array}{c}\text { Nuclear } \\
\text { genotype }\end{array}$ & $\begin{array}{c}\text { Fruit length } \\
(\mathrm{cm})\end{array}$ & $\begin{array}{c}\text { Fruit dia. } \\
(\mathrm{mm})\end{array}$ & $\begin{array}{c}\text { Fruit weight } \\
(\mathrm{g})\end{array}$ & $\begin{array}{c}\text { Pericarp thickness } \\
(\mathrm{mm})\end{array}$ \\
\hline KC980 & Fertile & N(S)RfRf & 11.8 & 16.1 & 12.5 & 2.7 \\
KC981 & Sterile & Nrfrf & 10.1 & 14.5 & 9.4 & - \\
KC995 & Fertile & N(S)RfRf & 8.0 & 9.7 & 4.3 & 1.3 \\
KC999 & Fertile & N(S)RfRf & 7.9 & 13.6 & 6.9 & 1.5 \\
KC1006 & Sterile & Nrfrf & 11.5 & 13.0 & 9.6 & 1.7 \\
KC1009 & Fertile & N(S)RfRf & 7.7 & 8.4 & 2.5 & 1.3 \\
KC1021 & Sterile & Nrfrf & 9.4 & 21.6 & 21.0 & 2.4 \\
KC1027 & Sterile & Nrfrf & 3.5 & 10.9 & 1.9 & 1.3 \\
KC1045 & Sterile & Nrfrf & 9.5 & 13.0 & 8.4 & 1.7 \\
KC1050 & Sterile & Nrfrf & 7.6 & 11.9 & 5.1 & 1.3 \\
KC1055 & Sterile & Nrfrf & 7.4 & 11.7 & 3.0 & 1.1 \\
KC350 & Fertile & N(S)RfRf & 9.6 & 19.4 & 10.6 & 1.7 \\
KC351 & Sterile & Nrfrf & 10.6 & 15.5 & 11.9 & 1.7 \\
\hline
\end{tabular}


the Vietnam collection were evaluated for detailed fruit morphology. All newly introduced accessions resistant to $R$. solanacearum produce red, hot fruits and were very uniform, indicating that they are homozygous. Most of them bear pendent fruits, except KC999 producing erect fruits. In comparison with $\mathrm{KC} 350$ and $\mathrm{KC} 351$, fruit sizes of lines originating from Vietnam seem smaller with exception of KC980 and KC1021 (Table 2). These additional materials will be valuable resources in breeding for resistance and nuclear restorer genotype information would be useful in planning the breeding programs for resistant $\mathrm{F}_{1}$ hybrids using cytoplasmic male sterility. Thus, the accessions with restorer genotype, $N(S) R f R f$, may be preferentially used in breeding lines for bacterial wilt resistant paternal parents and those with maintainer genotype, Nrfrf, for cytoplasmically male sterile maternal parents in hybrid breeding system.

\section{Acknowledgements}

This work was supported by a grant from the Regional Subgenebank Program, and Cooperative Research Project of Rural Development Administration (PJ006581), and also by a grant (710001-03-1) from the Vegetable Breeding Research Center through Agriculture Research Center (ARC) program from Ministry for Food, Agriculture, Forestry and Fisheries, Republic of Korea.

\section{References}

Arlat, M., Van Gijsegem, F., Pernollet, J. C., Huet, J. C. and Boucher, C. A. 1994. PopA1, a protein which induces a hypersensitive-like response on specific petunia genotypes, is secreted via the Hrp pathway of Pseudomonas solanaceraum. EMBO J. 13:543-553.

Carney, B. F. and Denny, T. P. 1990. A cloned avirulence gene from Pseudomonas solanaceraum determines incompatibility on Nicotiana tabacum at the host species level. J. Bacteriol. 172:4836-4843.

Doan, T. T., Le, T. T. T. and Nguyen, T. H. 2006. Research on bacterial wilt and Fusarium, and sustainable bio-control of the diseases on tomato. The second conference of Vietnam Molecular Plant Pathology Society and the $5^{\text {th }}$ National Conference on Plant Pathology and Molecular Biology, Hanoi Agriculture University, 20-22 Oct., 2006.

Hanson, P. M., Wang, J. F., Licardo, O., Hanudin, Mah, S. Y., Hartman, G. L., Lin, Y. C. and Chen, J. T. 1996. Variable reaction of tomato lines to bacterial wilt evaluated at several locations in Southeast Asia. HortScience 31:143-146.

Hashimoto, N., Matsumoto, S., Yoshikawa, M., Horita, M. and Tsuchiya, K. 2001. Varietal resistance among red pepper and sweet pepper cultivars to Ralstonia solanacearum isolated in Kyoto Prefecture [abstract in Japanese]. Jpn. J. Phytopathol.
67:201-202.

Hayward, A. C. 1994. The host of Pseudomonas solanaceraum. In: A.C. Hayward, G.L. Hartman (Eds.), Bacterial Wilt: The Disease and Its Causative Agent, Pseudomonas solanaceraum, CAB International, Wallingford.

Hayward, A. C. 2000. Ralstonia solanacearum. Encyc. Microbiol. 4:32-42.

Horita, M. and Tsuchiya, K. 2001. Genetic diversity of Japanese strains of Ralstonia solanacearum. Phytopathology 91:399407.

Horner, H. T. Jr and Rogers, M. A. 1974. A comparative light and electron microscopic study of microsporogenesis in male fertile and cytoplasmic male-sterile pepper (Capsicum annuum L.). Can. J. Bot. 52:435-441.

Kennet, R., Barkai-Golan, R., Chorin, M., Dishon, I., Katan, Y., Netzer, D., Palti, J. and Volcani, Z. 1970. A revised checklist of fungal and bacterial diseases of vegetable crops in Israel. Spec. Pub. Volcani Inst. Agric. Res. Bet Dagan: 39.

Kim, B. S., Cheung, J. D., Cha, Y. S. and Hwang, H. S. 1998. Resistance to bacterial wilt of introduced peppers. Korean $J$. Plant Pathol. 14:217-219.

Kim, B. S., Han, J. H., Joo, Y. S. and Kim, J. H. 2004. Genotyping of the sources of resistance to bacterial wilt in pepper (Capsicum annuиm $\mathrm{L}$ ) with respect to fertility - restoring gene interaction with male sterile cytoplasm. J. Kor. Soc. Hort. Sci. 45: 27-30.

Lee, D. H. 2001. Studies on unstable fertility of CGMS (cytoplasmic-genic male sterility) in Capsicum annuum L. Dissertation, Seoul National University.

Matos, F. S. A., Lopes, C. A. and Takatsu, A. 1990. Identification of sources of resistance to Pseudomonas solanacearum in Capsicum spp. Hort. Bras. 8:22-23.

Mimura, Y. and Yoshikawa, M. 2009. Pepper accession LS2341 is highly resistant to Ralstonia solanacearum strains from Japan. HortScience 44:2038-2040.

Novak, F., Betlach, J. and Dubovsky, J. 1971. Cytoplasm male sterility in sweet pepper (Capsicum annuum L.). Z. Pflanzenzcht 65:129-140.

Peterson, P. A. 1958. Cytoplasmically inherited male sterility in Capsicum. Amer. Nat. 92:111-119.

Rahman, M. A., Abdullah, H. and Vanhaecke, M. 1999. Histopathology of susceptible and resistant Capsicum annuum cultivars infected with Ralstonia solanacearum. J. Phytopathol. 147:129-140.

Schaad, N. W., Jones, J. B. and Chun, W. 2001. Laboratory guide for identification of plant pathogenic bacteria. $3^{\text {rd }}$ ed. APS Press, St. Paul, Minnesota.

Shifriss, C. and Guri, A. 1979. Variation in stability of cytoplasmic - gene male sterility in Capsicum annum L. J. Amer. Soc. Hort. Sci. 104:94-96.

Shifriss, C. and Frankel, R. 1971. New sources of cytoplasmic male sterility in cultivated peppers. J. Hered. 62:254-256.

Shifriss, C. 1997. Male sterility in pepper (Capsicum annuum L.). Euphytica 93:83-88.

Tanksley, S. D. 1984. High rates of cross- pollination in chile pepper. HortScience 19:580-582. 
Tran, N. H. and Kim, B. S. 2007. Search for sources of resistance to bacterial spot (Xanthomonas campestris pv. vesicatoria) in Capsicum pepper. Acta Hort. 760:323-328.

Tran, N. H. and Kim, B. S. 2010. Inheritance of resistance to bacterial wilt (Ralstonia solanacearum) in pepper (Capsicum annuum L.). Hort. Environ. Biotechnol. 51:431-439.

Yu, I. O. 1990. The inheritance of male sterility and its utilization for breeding in pepper (Capsicum spp.). Ph.D. Dissertation, Kyung Hee University, South Korea. 